Int. J. Dev. Biol. 54: 545-553 (2010)

doi: $10.1387 / \mathrm{ijdb} .0827711 \mathrm{~m}$

\title{
Role of fetal membranes in signaling of fetal maturation and parturition
}

\author{
LESLIE MYATT**,1 and KANG SUN ${ }^{2}$ \\ ${ }^{1}$ Dept. of Obstetrics and Gynecology, University of Texas Health Science Center San Antonio, USA and \\ ${ }^{2}$ School of Life Sciences, Fudan University, Shanghai, P.R. China
}

\begin{abstract}
The fetal membranes fulfill several functions during pregnancy. In addition to containing the products of conception and amniotic fluid, they presumably have barrier functions and fulfill paracrine signaling functions between the maternal (decidual) and fetal compartments. As the membranes are in an ideal place to receive both maternal and fetal signals and transmit signals to uterine myometrium, there has been a specific focus on the role of membranes in the initiation and maintenance of parturition. In this review, we summarize the data obtained in our laboratories as well as the data reported in the literature particularly with regard to the synthesis of steroids and prostaglandins in the fetal membranes, in signaling fetal maturation and in parturition. The fetal membranes are a major site both of prostaglandin synthesis and of prostaglandin metabolism. In addition, the abundant expression of 11beta-hydroxysteroid dehydrogenase 1 (11ß-HSD1), which converts biologically inactive cortisone into active cortisol, in the fetal membranes may provide an extra-adrenal source of glucocorticoids for the fetal compartment during gestation. Accumulating evidence indicates that a positive feedback loop involving glucocorticoids, proinflammatory cytokines, prostaglandins, surfactant protein-A (SP-A) and 11 $\beta$ HSD1 is formed locally in human fetal membranes towards term or in preterm labor. This positive feedback loop would produce abundant biologically active glucocorticoids and prostaglandins in the fetal membranes or amniotic fluid, which would ultimately promote fetal organ maturation and initiate parturition.
\end{abstract}

KEY WORDS: fetal membrane, prostaglandin, glucocorticoid, fetus, parturition

At term the human fetal membranes comprised of amnion and chorion tissue layers are approximately $1000-1200 \mathrm{~cm}^{2}$ in area with $30 \%$ of this overlying the placenta and the remaining $70 \%$ being the reflected membranes that interact with decidua. The fetal surface of the membranes is composed of a single layer of amnion epithelium supported by a basement membrane resting on a thick collagen layer containing fibroblasts. The ratio of epithelial cells to fibroblasts in amnion is approximately 10 to 1. A thin spongy layer connects the collagen layer to the chorion leave comprised of cytotrophoblasts and these trophoblasts contact the decidua. The fetal membranes fulfill several functions during pregnancy. In addition to containing the products of conception and amniotic fluid, they presumably have barrier functions and fulfill paracrine signaling functions between the maternal (decidual) and fetal compartments. Unlike many animals the human fetal membranes are not vascularized which probably severely limits their functioning as an exchange surface for nutrients between mother and fetus. As the membranes are in an ideal place to receive both maternal and fetal signals and transmit signals to uterine myometrium there has been a specific focus on the role of membranes in the initiation and maintenance of parturition, particularly with regard to their synthesis of steroids and prostaglandins. Glucocorticoids are now known to play key roles in fetal maturation for example in maturation of the lung in anticipation of extra-uterine life and in several species appear to be mediators in the initiation of labor. Teleologically it could be expected that as part of an integrated signaling pathway glucocorticoids may play a role in maturation and in the initiation of parturition. This has been clearly shown in animal species e.g. the sheep, however the evidence is less clear in humans. In addition to being influenced by maternal or fetal circulating steroids the

Abbreviations used in this paper: Hsd, hydroxysteroid dehydrogenase.

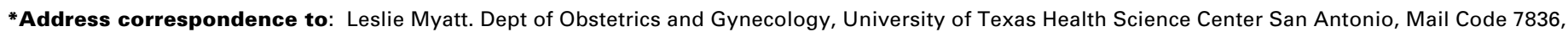
7703 Floyd Curl Drive, San Antonio TX 78229-3900, USA. Fax: +1-210-567-5033. e-mail: MyattL@uthscsa.edu
} 
fetal membranes also locally synthesize and metabolize steroids in particular glucocorticoids. This review will focus on the role of the fetal membranes and particularly the interaction of glucocorticoids and prostaglandins in the signaling processes of fetal maturation and parturition.

\section{Prostaglandin synthesis and metabolism in fetal mem- branes}

Prostaglandins have an important role in the initiation and maintenance of labor (Gibb, 1998). The fetal membranes are a major site both of prostaglandin synthesis and of prostaglandin metabolism, which however may be compartmentalized in the different cell types comprising the membranes. The prostaglandins are powerful stimulants to the pregnant myometrium with the amount reaching the myometrium being dependent on the expression and activity of the prostaglandin synthases (PGHS) in amnion and chorion and expression of 15 hydroxy prostaglandin dehydrogenase (PGDH) activity in chorion trophoblast which balances synthesis and metabolism respectively to prevent or limit prostaglandins from amnion reaching the myometrium prior to term. Indeed we (Bennett et al., 1990; Mitchell et al., 1993; Nakla et al., 1986) and others have shown that very little prostaglandin can pass the fetal membranes without being converted to an inactive metabolite thus demonstrating the efficacy of the barrier. Not only is synthesis increased but the activity and expression of PGDH in chorionic trophoblast is significantly lower at term from patients in labor thus potentially allowing more active prostaglandin to cross to myometrium (Pomini et al., 2000). The regulation of PGDH expression has been extensively studied. Several agents have been shown to have a reciprocal effect on $P G$ synthesis and metabolism with agents that stimulate expression of $P G H S$ and $P G$ synthesis inhibiting PGDH and vice versa (Casciani etal., 2008). Thus the amount of synthesis and metabolism of PG's by the fetal membranes and the amount of bioactive PG's available is tightly controlled. Corticotropin-releasing hormone $(\mathrm{CRH})$ acting via a calcium-dependent pathway stimulates PGDH activity on chorionic trophoblast (McKeown et al., 2003). Cortisol decreases and progesterone maintains PGDH activity both steroids acting via the PR and GR receptors (Patel et al., 2003). Thus any increase in cortisol or reduction in progesterone concentrations at term might allow more active prostaglandin to reach the myometrium from the fetal membranes. Further in individuals with preterm labor with infection a reduction in the number of chorion trophoblast cells expressing PGDH activity compared to patients with idiopathic preterm labor has been demonstrated which would allow more bioactive PG's to pass to myometrium (Van Meir et al., 1996).

\section{Phospholipases}

Increased prostaglandin synthesis by fetal membranes occurs both in normal term labor and in preterm labor (Bleasdale et al., 1984). The substrate for prostaglandin synthesis is arachidonic acid in cellular membranes from where it is liberated by phospholipiase enzymes particularly phospholipase $A_{2}$. There are at least 15 different isoforms of phospholipase $A_{2}$ with differing cellular locations and functions (Schaloske et al., 2006). We and others have shown the role of type IV or $85 \mathrm{kDa}$ cytosolic phospho- lipase $A_{2}$ in fetal membranes, particularly amnion. Cytosolic PLA activity in human amnion increases with gestational age and is highest at term in the absence of labor (Skannal et al., 1997). The crucial role of $\mathrm{CPLA}$ in parturition is illustrated by the finding that $\mathrm{cPLA}_{2}$ null mice failed to deliver offspring (Uozumi et al., 1997). The enzyme translocates from cytosol to nuclear membrane when phosphorylated under cytokine stimulation but in addition de novo expression of both cPLA ${ }_{2}$ (Xue et al., 1995) and PGHS2 is rapidly stimulated by cytokines as immediate early genes. This gives rapid inducible expression of these two enzymes to liberate arachidonic acid and convert it to PG endoperoxide, $\mathrm{PGH}_{2}$, in a coordinated manner in a condition where sustained production of $\mathrm{PGE}_{2}$, e.g. parturition, is required. The PGHS-2 enzyme is also located on the nuclear envelope hence the two enzymes appear to be functionally coupled at a distinct cellular location.

\section{Prostaglandin synthases}

The conversion of arachidonic acid to $\mathrm{PGH}_{2}$ is catalyzed by one of the two isoforms of prostaglandin $\mathrm{H}$ synthase (PGHS). PGHS-1 is constitutively expressed whereas PGHS-2 can be induced by pro-inflammatory cytokines such as IL-1 $\beta$. In fetal membranes the increase in $P G$ synthesis at term, mainly $P G E_{2}$, is clearly associated with increased expression of PGHS-2 (Gibb and Sun 1996; Mijovic et al. 1997). The unstable PG endoperoxide $\mathrm{PGH}_{2}$ can be converted to a range of primary PG's by various specific synthases (Smith, 1992). The PGE synthase enzyme occurs as cytosolic (cPGES) and microsomal (mPGES) isoforms. cPGES is identical to p23, a 23kDa chaperone that binds to heat shock protein 90 (Weaver et al., 2000) and appears to be constitutively expressed. In addition cPGES associates with and is phosphorylated by casein kinase 2 (Kobayashi et al., 2004) leading to $\mathrm{cPGES}$ activation and increased $\mathrm{PGE}_{2}$ production. Hsp 90 appears to be the cellular scaffold that allows a stoichiometric complex to form between casein kinase 2, hsp90 and cPGES. Cotransfection and antisense experiments show cPGES is coupled to PGHS-1 (Han et al., 2002). Human mPGES-1 is a $16 \mathrm{kDa}$ protein related to microsomal glutathione transferase-1, and is an inducible member of the MAPEG (membrane associated protein involved in eicosanoid and glutathione metabolism) superfamily (Forsberg et al., 2000). This enzyme can be induced by LPS and cytokines (Mancini et al., 2001) and appears to co-localize with PGHS-2 in the perinuclear membrane (Kudo et al., 1999; Thoren et al., 2000). The other membrane associated form of PGES is mPGES-2, which has a catalytic glutaredoxin/thioredoxin-like domain (Tanikawa et al., 2002) and is synthesized as a Golgimembrane bound protein but which ends up in cytosol after proteolytic cleavage of the $\mathrm{N}$-terminal hydrophobic domain. This isoform appears to couple to either PGHS-1 or -2 (Murakami etal., 2003) and is constitutively expressed.

We have provided data showing the cellular localization of cPGES and mPGES-1 in human fetal membranes (Meadows et al., 2003). Cytosolic PGES was localized to amnion epithelium, amnion fibroblasts and macrophages in the chorion trophoblast layer. Microsomal PGES-1 was localized to amnion epithelium and chorion trophoblast. By western bot analysis we found no difference in cellular expression of mPGES-1 or cPGES with or without labor either at term or preterm (Meadows et al., 2003). 
This suggested expression of the PGE synthases was not rate limiting for $P G$ synthesis at labor but that expression of $\mathrm{CPLA}_{2}$ or PGHS-2 probably was.

\section{Glucocorticoids and prostaglandin synthesis in fetal membranes}

Glucocorticoids are commonly used in the treatment of immune and inflammatory disorders. A characteristic anti-inflammatory action of glucocorticoid action is that it suppresses cytokineinduced prostaglandin synthesis (Hoeck et al., 1993; Newton et al. 1997). We had previously shown that glucortoicids suppress cytokine induced cPLA ${ }_{2}$ and PGHS expression in an immortalized amnion epithelial cell line (Xue et al., 1996). In certain cells, however, glucocorticoids act paradoxically by stimulating rather than inhibiting PG production, such as in rat gastric mucosa, murine fibroblast, and fetal rat lungs (Avunduk et al., 1992; Chandrabose et al., 1978; Tsai et al., 1983). Interestingly, there are equally massive increases in plasma levels of both cortisol and PGs during parturition (Casey et al., 1985). In human fetal membrane primary cell culture glucocorticoids were found to paradoxically stimulate $\mathrm{PGE}_{2}$ synthesis. (Zakar et al. 1995; Economopoulos et al. 1996). In amnion tissue both amnion epithelial cells and fibroblasts express $\mathrm{cPLA}_{2}$, PGHS-2 and PGE synthase enzymes. However glucocorticoids only appear to stimulate $\mathrm{PGE}_{2}$ synthesis in fibroblasts (Blumenstein et al., 2000; Gibb et al., 1990). Amnion fibroblasts produce about 50x more $\mathrm{PGE}_{2}$ per cell than amnion epithelium, making them the most abundant source of $\mathrm{PGE}_{2}$ despite being outnumbered 10 fold by epithelial cells (Sun et al., 2003), which could be attributed to their higher expression of PGHS-2 compared to epithelium, with no difference in expression of $\mathrm{CPLA}_{2}, \mathrm{CPGES}$ or $\mathrm{MPGES}-1$. Hence fibroblasts may be the major source of $\mathrm{PGE}_{2}$ at parturition. Glucocorticoids clearly give a concentration dependent stimulation of $\mathrm{PGE}_{2}$ synthesis in fibroblasts which is accompanied by up-regulation of $\mathrm{CPLA}_{2}$ and PGHS-2 expression (Sun et al. 2003). In contrast in the same experiments glucocorticoids had no effect on CPGES or mPGES-1 expression. The induction of $\mathrm{CPLA}_{2}$, PGHS-2 expression and of $\mathrm{PGE}_{2}$ release by glucocorticoids was blocked by RU486 which however blocks both GR and PR (Mahajan et al., 1997). As amnion has no reported $P R$ and trilostane an inhibitor of $3 \beta \mathrm{HSD}$ and endogenous progesterone synthesis did not affect $\mathrm{CPLA}_{2}, \mathrm{PGHS}-2$ and $\mathrm{PGE}_{2}$ output of amnion fibroblasts we believe the effect of RU486 is via GR rather than PR (Sun et al. 2003).

Early studies using an immortalized amnion epithelium cell line, WISH cells, showed that dexamethasone decreased cytokine induced $\mathrm{CPLA}_{2}$ and PGHS-2 expression and activity (Xue et al., 1996) via interference with transcription factor binding at NFkB and CRE in the gene promoters (Wang et al., 1998) Subsequently we demonstrated that both dexamethasone and II-1 $\beta$ induced $\mathrm{PGE}_{2}$ output, $\mathrm{cPLA} \mathrm{A}_{2} \mathrm{mRNA}$ and protein expression in primary amnion fibroblasts (Sun et al., 2006b). Using a cPLA $A_{2}$ promoter reporter construct we demonstrated that the effect was not agonistic or synergistic. More recently we have shown with chromatin immunoprecipitation (ChIP) and electrophoretic mobility shift assays that this paradox of glucocorticoid induction of $\mathrm{CPLA}_{2}$ expression involves direct binding of the GR to the gene promoter in amnion fibroblasts (Guo et al., 2008).

\section{Cortisol in the fetal circulation}

Glucocorticoids have been implicated in the process of fetal maturation, in the regulation of immune response and many other physiological changes associated with pregnancy (Gonzales et al., 1986; Whittle et al., 2001). Studies in animals suggest that fetal cortisol may also have a critical role in the initiation of parturition (Challis et al. 2000; Whittle et al. 2001; Liggins and Thorburn 1994; Jenkin and Young 2004). In sheep, the fetal adrenal glands produce increasing amount of cortisol toward the end of pregnancy as a result of maturing hypothalamus-pituitaryadrenal axis (HPA axis). Upon reaching the placenta, this cortisol is capable of stimulating the expression of crucial enzymes involved in the synthesis of estrogen and prostaglandins which may stimulate uterine contractility. One of the enzyme induced by cortisol is $\mathrm{P}_{450} \mathrm{C}_{17}$ hydroxylase $\left(\mathrm{P}_{450} \mathrm{C}_{17}\right)$, which converts progesterone to estrogen (Anderson et al., 1975; Flint et al., 1978; Ma et al., 1999). Increased expression of $\mathrm{P}_{450} \mathrm{C}_{17}$ leads to the surge of estrogen and fall in progesterone level at the end of pregnancy. Another enzyme induced by cortisol is PGHS-2) which is a key inducible enzyme in prostaglandin synthesis (Wu et al., 2001).

The situation in man appears to be much more complicated. Although cortisol may also up-regulate the expression of prostaglandin synthesizing enzymes (Zakar et al. 1995; Economopoulos et al. 1996; Blumenstein et al. 2000), and the synthesis of corticotrophin-releasing hormone (CRH) (Cheng et al., 2000; Karalis et al., 1996; McLean et al., 1995) in human placenta and fetal membranes, due to the lack of $\mathrm{P}_{450} \mathrm{C}_{17}$ in human placenta the synthesis of estrogen is dependent on the precursor dehydroepiandrosterone sulfate (DHEAS) but not on progesterone (Challis et al., 2000). Therefore, despite the progressive rise of glucocorticoid level in both maternal, fetal circulations and in amniotic fluid with gestational age, both progesterone and estrogen levels rise with gestational age in human pregnancy (Casey et al. 1985; Challis et al. 2000). Maternal and fetal adrenal glands are the two major sources for DHEAS during pregnancy. To meet the need for estrogen synthesis by the placenta in pregnancy, the size of human fetal adrenal glands is disproportionally large with regard to the body size, and which does not disappear until the first three months of extrauterine life (Mesiano and Jaffe 1997). A large proportion of the adrenal glands of human fetus is comprised of the fetal zone which synthesizes DHEAS, whereas the transitional and definitive zones capable of synthesizing cortisol only comprise a small portion of the fetal adrenal glands (Mesiano et al., 1997). Furthermore, 33-HSD, the enzyme responsible for the de novosynthesis of cortisol from cholesterol is not expressed in the fetal adrenal glands until the last trimester of gestation (Mesiano et al., 1997). Therefore, the principle steroids produced by human fetal adrenal glands are DHEA and DHEAS rather than cortisol during gestation. However, they may synthesize a small amount of cortisol from as early as 10 weeks of gestation using progesterone as the precursor (Mesiano et al., 1997). With the appearance of $3 \beta-\mathrm{HSD}$ expression by the end of gestation, human fetal adrenal glands may start synthesizing a limited amount cortisol from cholesterol (Ohrlander et al., 1976; Mesiano and Jaffe 1997). Therefore, compared with other animals, the cortisol concentration in the human fetus rises more slowly and to a more modest extent at the end of gestation. In contrast the cortisol level in maternal circulation and amniotic fluid rises 
dramatically, reaching micromolar concentration at late gestation (Blankstein et al., 1980).

The unique structure and function of human fetal adrenal glands may benefit the normal development of the fetus by means of maintaining estrogen production in the placenta and low cortisol levels in fetal circulation during pregnancy, as high levels of circulating glucocorticoids are known to be teratogenic to the growing fetus (Seckl et al., 2000; Shams et al., 1998). The low cortisol level in the fetal circulation is further ensured by the presence of $11 \beta$-hydroxysteroid dehydrogenase type 2 (11 $\beta$ HSD2) in the placenta and fetal tissues (Seckl et al., 2000; Shams et al., 1998). 11 $\beta$-HSD2 is a NAD dependent oxidase capable of converting cortisol into biologically inactive cortisone (Draper et al., 2005; Seckl, 1993). Immunohistochemistry revealed this highly efficient enzyme is localized in the syncytiotrophoblast layer of human placenta (Krozowski et al., 1995), which fits perfectly into the role of $11 \beta$-HSD2 as a placental glucocorticoid barrier preventing the passage of maternal cortisol (about 10 fold higher than fetal cortisol) into the fetal circulation. Moreover, as a self-protective measure, most human fetal tissues also express $11 \beta$-HSD2 from early in gestation (Murphy 1981; Stewart et al., 1994). As a result of the action of $11 \beta-H S D 2$ in both placental and fetal tissues, human placenta and fetal blood contain a relatively large amount of cortisone (Bro-Rasmussen et al., 1962; De Courcy et al., 1952; Lopez Bernal et al., 1981), and the ratio of plasma cortisol/cortisone is reversed in the fetus (1:2) compared with that in the adult (10:1) (Bro-Rasmussen etal., 1962; Whitworth et al., 1989). Therefore, the biologically inactive cortisone rather than cortisol is the major glucocorticoid hormone in the fetal circulation. However, as glucocorticoids are indispensable for fetal organ maturation and possibly for parturition as well, a rise of glucocorticoid level, though modest, does occur towards the end of pregnancy in fetal circulation. This can be achieved by several factors including weakened placenta glucocorticoid barrier (Ohrlander et al. 1976; Giannopoulos et al. 1982), attenuated $11 \beta$-HSD2 expression in the fetal tissues (Diaz et al., 1998; Murphy, 1981), increased synthesis of cortisol by the fetal adrenal glands (Seron-Ferre et al., 1978) and increased expression of $11 \beta$-HSD1 in the fetal tissues including the fetal membranes, which regenerate cortisol from cortisone (Alfaidy et al., 2003; Diaz et al., 1998; Tanswell et al., 1977). As a large amount of cortisone is present in the placenta and fetal compartment, the regeneration pathway in the fetal tissues might provide an important source of cortisol for fetal maturation and parturition towards the end of gestation.

\section{$11 \beta$-hydroxysteroid dehydrogenase type 1 in human fetal membranes as an extra-adrenal source of gluco- corticoids in gestation}

The regeneration of cortisol from cortisone is achieved by $11 \beta$ HSD1, an isozyme of $11 \beta$-HSD2. $11 \beta$-HSD1 is a NADPH dependent oxoreductase (Seckl 1993; Draper and Stewart 2005). In intact cells, it mainly functions as a reductase converting cortisone to cortisol or dehydrocorticosterone to corticosterone, which is in obvious contrast to 11ß-HSD2 (Seckl 1993; Draper and Stewart 2005). Despite the highly efficient conversion of cortisol to cortisone by $11 \beta$-HSD2 in the placenta and fetal tissues, the cortisol/cortisone ratio of amniotic fluid increases steadily with gestational age and is considerably higher than that of cord serum (Blankstein et al., 1980), suggesting fetal membranes might be another source for cortisol during gestation. Interestingly, this ratio is significantly lower in the amniotic fluid of infants who develop respiratory distress syndrome (Smith et al., 1977), suggesting this cortisol source might be very important in fetal lung maturation. This notion is supported by the observation that some anencephalic infants seemed to breathe at birth despite poor adrenal function (Burke et al., 1973), indicating absorption of amniotic cortisol through the lung or open cranium. Tanswell et al., reported that human amnion increasingly converted cortisone to cortisol during pregnancy, thereby potentially contributing to the increasing cortisol concentration in the amniotic fluid (Tanswell et al., 1977). Although there were studies suggesting the chorion itself is devoid of $11 \beta-H S D$ reductive activity (Lopez Bernal et al., 1980; Stewart et al., 1995), Murphy observed that chorion with adherent decidua carefully scraped off retained a high degree of conversion of cortisone to cortisol and that the rise in chorionic conversion of cortisone to cortisol in early pregnancy corresponds to the rise at 15-20 weeks in amniotic fluid cortisol (Murphy, 1977). Gionaopoulos et al., demonstrated a high degree of reductive glucocorticoid metabolism in the decidua attached to chorion (Giannopoulos et al., 1982). Together these observations indicate a role of fetal membranes and attached decidua in regeneration of cortisol from cortisone during pregnancy. Following the successful cloning of human $11 \beta$-HSD1 and $11 \beta$-HSD2 genes (Tannin et al. 1991; Lakshmi et al. 1993), distinguishing $11 \beta$ HSD1 and 11 $\beta$-HSD2 expression in human placenta and fetal membranes became possible. Using immunohistochemistry, Sun et al., showed that $11 \beta$-HSD1 protein was present in amnion epithelial cells, in fibroblasts within the subepithelial layer and in the chorionic trophoblast layer as well as in the decidual stromal cells that were adherent to the chorion (Sun et al., 1997a). These findings were conclusively supported by studies showing $11 \beta$ HSD1 mRNA and activity were detectable in cultured human amnion epithelial cells, amnion fibroblasts and chorionic trophoblasts (Sun et al., 2003) although it appeared that amniotic fibroblasts and chorionic trophoblasts attained higher degree of $11 \beta$-HSD1 expression than amnion epithelial cells. In contrast Northern blotting analysis failed to detect any $11 \beta-H S D 2$ mRNA in the amnion and chorion tissues in agreement with the observation showing little $11 \beta$-HSD2 activity in cultured chorionic trophoblasts (Sun et al., 1997b).

Although it is generally believed that human placenta mainly expresses $11 \beta$-HSD2, increased conversion of cortisone to cortisol in homogenized human placental tissue toward term was reported, although conversion from cortisol to cortisone predominated at all gestational ages (Murphy 1981; Giannopoulos et al. 1982). Further studies indicated human placenta $11 \beta-H S D$ was a reversible enzyme system, and there were at least two species of $11 \beta$-HSD in human placenta (Lakshmi et al., 1993). Sun et al., demonstrated that this reversible enzyme system was more likely to be attributed to the expression of $11 \beta$-HSD1 in human placenta (Sun et al. 1997; Sun et al. 1999). Immunohistochemistry revealed $11 \beta$-HSD1 was expressed in the extravillous cytotrophoblasts and vascular endothelium lining the fine branches of the umbilical blood vessels in the tertiary villi but not in the syncytiotrophoblasts (Sun et al., 1997a). The cellular distribution of $11 \beta-H S D 1$ in human placenta is clearly different from that of 


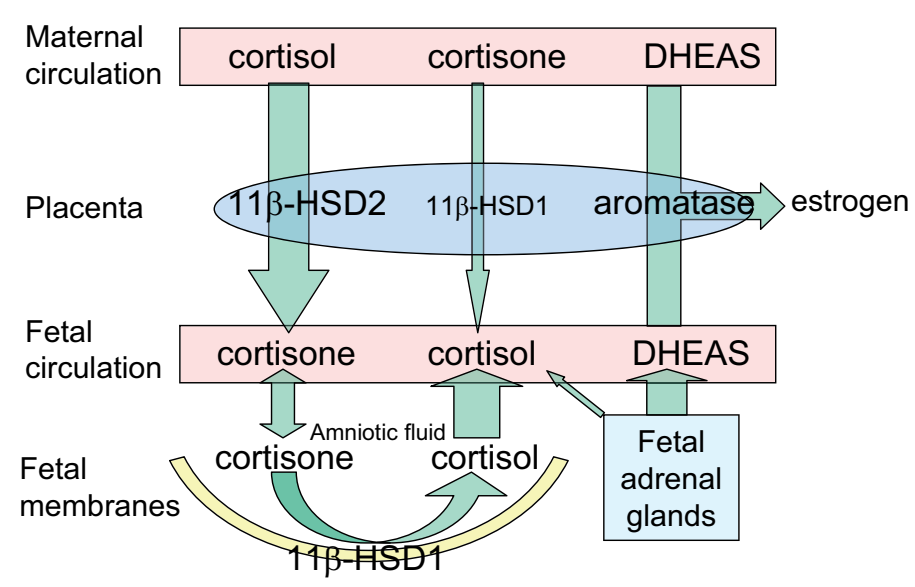

Fig. 1. Interconversion of glucocorticoids in placenta and fetal membranes. The differential expression of $11 \beta$-hydroxysteroid dehydrogenase (HSD) isoforms in placenta and fetal membranes regulates the metabolism and transport of active cortisol and inactive cortisone between maternal and fetal circulations.

$11 \beta$-HSD2, which was found only in the syncytiotrophoblasts. Placental perfusion studies demonstrated that a substantial amount of cortisol was detected on the fetal side when cortisone was infused into the intervillous space on the maternal side, further suggesting the presence of $11 \beta$-HSD1 in human placenta (Sun et al., 1999). As the placenta controls the amount of glucocorticoid reaching the fetus, this dual $11 \beta-H S D$ enzyme system in human placenta may interact in a concerted fashion to provide a precise mechanism to control the passage of maternal glucocorticoids to the fetal circulation, in particular, towards the end of pregnancy.

The evidence is fairly clear now that $11 \beta$-HSD1 and $11 \beta$-HSD2 are differentially expressed in human fetal membranes and placenta. The highly vascular placenta mainly expresses $11 \beta-H S D 2$ with strong oxidative activity while its avascular counterpart, the fetal membranes, mainly express $11 \beta$-HSD1 with strongly reductive activity in terms of glucocorticoid metabolism (Fig. 1). This distribution pattern of $11 \beta$-HSD1 and 2 in human placenta and fetal membranes not only fits well into the critical role of $11 \beta$-HSD2 as a barrier to glucocorticoid passage in the placenta, but also indicates the avascular fetal membranes to be a metabolically active tissue which behaves differently from the placenta. Studies have shown that the expression level and reductive activity of $11 \beta$-HSD1 in the fetal membranes increases with gestational age (Tanswell etal. 1977; Alfaidy etal. 2003), which coincides with the increase of cortisol level in the amniotic fluid and fetal circulation (Blankstein et al., 1980), further suggesting 11 $\beta$-HSD1 in the fetal membranes be a likely source of cortisol for the fetal compartment during gestation.

\section{Feed forward induction of $11 \beta$-hydroxysteroid dehy- drogenase type 1 expression in fetal membranes, an indispensable mechanism required for fetal matura- tion and parturition?}

Chorioamnionitis is the most common type of infection in preterm labor, especially in preterm rupture of membranes and has been recognized to be the leading cause for preterm labor
(Smaill, 1996). Infection of membranes results in the activation of macrophages in these tissues. The activated macrophages then release proinflammatory cytokines such as IL-1b and TNFa and activate local stromal cells that further release proinflammatory cytokines (Smaill, 1996). Both IL-1b and TNFa are key factors in infection-induced preterm labor (Bowen et al., 2002). They stimulate prostaglandin synthesis in the fetal membranes as well as increase the production of estrogen and $\mathrm{CRH}$ in the placenta (Nestler, 1993; Petraglia et al., 1990). It has been reported that IL$1 \mathrm{~b}$ and TNFa induced 11b-HSD1 expression in ovary, kidney, adipose tissue and osteoblast cells (Cooper et al., 2001; Escher et al., 1997; Tomlinson et al., 2001; Yong et al., 2002). We found that IL-1b and TNFa induced 11b-HSD1 expression in fibroblast cells and trophoblast cells derived from human fetal membranes (Li et al., 2006; Sun et al., 2003). Recently it was found that both IL-1 $\beta$ and TNF $\alpha$ utilize the CCAAT consensus sequences in 11 $\beta$ HSD1 promoter to upregulate its expression (Yang et al., 2009; Ignatova et al., 2009).

Analysis of the human $11 \mathrm{~b}-\mathrm{HSD} 1$ gene promoter revealed a putative glucocorticoid response element (GRE) and several CCAAT consensus sequences (Tannin et al., 1991). Glucocorticoids up-regulate 11b-HSD1 expression in a number of tissues or cell types (Tomlinson et al., 2004) and we demonstrated that glucocorticoids induced 11b-HSD1 expression in fibroblast cells and trophoblast cells derived from human fetal membranes at concentrations easily achieved at the end of pregnancy (Sun and Myatt 2003; Li et al. 2006; Yang et al. 2007). We found this induction of $11 \beta$-HSD1 expression by glucocorticoids was a GR mediated on-going transcriptional process and verified the CCAAT consensus sequence and a GRE existing within the promoter region responsible for the induction of $11 \beta$-HSD1 by glucocorticoids (Yang et al., 2007).

It is well recognized that glucocorticoids effectively suppress immune cell activation induced by proinflammatory cytokines by two main mechanisms (McKay et al., 1999). Glucocorticoids inactivate the function of the proinflammatory cytokine mediator nuclear factor $-\kappa \mathrm{B}(\mathrm{NF}-\kappa \mathrm{B})$ by inducing the expression of inhibitory I $\mathrm{B}$ (McKay et al., 1999). This additional inhibitory $I_{\kappa} B$ holds NF $\kappa B$ in its inactive form in the cytoplasm (McKay et al., 1999). Additionally, the potential binding of activated nuclear GR complexes to nuclear NF $\kappa$ B may prevent the latter from binding to appropriate DNA response elements and contribute to steroid-mediated immunosuppression (McKay et al., 1999). However, we found the combination of glucocorticoids and proinflammatory cytokines further induced the expression of $11 \beta$-HSD1 mRNA in amnion fibroblasts and chorion trophoblasts, which is in obvious contrast to the opposing effects of glucocorticoids and proinflammatory cytokines at the inflammation site. The synergistic induction of $11 \beta$-HSD1 expression in human fetal membranes by glucocorticoids and proinflammatory cytokines (Sun et al. 2002; Sun and Myatt 2003; Li et al. 2006) may thus form a feed forward loop in terms of cortisol regeneration. As a result, there would be more and more biologically active glucocorticoids formed in the fetal membranes and diffused into amniotic fluid by the end of gestation, especially when the fetus is threatened by infection and subjected to high level of glucocorticoids. The increased regeneration of cortisol would not only provide a self-resolving mechanism to control inflammation, but also might promote fetal organ maturation and initiate parturition, to protect the fetus from the 
deteriorating detrimental effects of infection. This pattern of cortisol regeneration in the fetal membranes might be one of the feed forward mechanisms involved in fetal maturation and parturition.

\section{Networks of glucocorticoids, surfactant protein A and prostaglandins in human fetal membranes}

Although the specific mechanisms initiating parturition may vary among different species, glucocorticoids have been proposed as the factor synchronizing fetal maturation with the triggering mechanisms of parturition in nearly all species studied (Jenkin et al., 2004). Glucocorticoids accelerate lung maturation by enhancing surfactant synthesis in the pulmonary alveolar cells (Gonzales et al., 1986; Snyder et al., 1981). During fetal development, the type II alveolar cells of fetal lung eventually synthesize and release surfactant into pulmonary secretions (Van Golde et al., 1988), which is intermittently discharged into the amniotic fluid (Pryhuber et al., 1991; Snyder et al., 1988). Surfactant is a complex mixture consisting of phospholipids, nonpolar lipids, and proteins (Van Golde et al. 1988; Floros and Phelps 1997). One of the most abundant apoproteins specifically associated with pulmonary surfactant is surfactant protein A (SP-A) (Floros et al., 1997). SP-A concentration in the amniotic fluid increases dramatically in the third trimester of pregnancy, from less than $3 \mu \mathrm{g} / \mathrm{ml}$ at 30-31 wk to greater than $24 \mu \mathrm{g} / \mathrm{ml}$ at 40-41 wk (Snyder et al. 1988; Pryhuber et al. 1991). The phospholipid contained in surfactant provides a source of arachidonic acid that can be used by the amnion for prostaglandin synthesis (Lopez Bernal et al., 1989; Newman et al., 1993). In addition, it has been reported that SP-A plays important roles in the regulation of immune function in the fetal lung, including stimulating proinflammatory cytokine expression and activation of the Toll-like receptors (TLR) (Crouch et al., 2001). SP-A has been shown to bind to TLR2 and TLR4 (Guillot et al., 2002; Murakami et al., 2002) leading to NFкB activation. Recently Condon et al., provided direct evidence pointing to SP-A as the key link between the maturing fetus and the initiation of parturition in the mouse (Condon et al., 2004) as injection of SP-A into mouse amniotic fluid caused preterm labor, which was blocked by injection of the NF $\kappa$ B inhibitor SN50. These findings suggest that prostaglandin-synthesizing enzymes in the fetal membranes are possible targets for SP-A.

Both SP-A and other apoproteins such as SP-B and SP-D are present in the amniotic epithelium and chorio-decidual layers (Miyamura et al., 1994). Because high levels of surfactant proteins are present in the amniotic fluid at late gestation, adsorption or absorption of surfactant proteins onto or into the fetal membranes is likely to occur. Adsorption of SP-B onto the human amnion epithelium was demonstrated by Newman etal., (Newman et al., 1991). Although SP-A has been reported to be hydrophilic rather than hydrophobic unlike other surfactant proteins (Hawgood et al., 1990), these observations raised the possibility of absorption or adsorption of SP-A into the fetal membranes rather than local synthesis. In spite of these possibilities, we found that both SP-A protein and mRNA were present in amniotic epithelial cells, fibroblasts, and chorionic trophoblasts (Sun et al., 2006a), suggesting local synthesis of SP-A exists in all these three cell types of the fetal membranes. However, uptake of SP-A from the amniotic fluid by cells in the fetal membranes cannot be totally ruled out because the most intensive staining of SP-A protein was observed in the amnion epithelium, especially the apical membrane facing the amniotic fluid, but the expression of SP-A mRNA in amniotic epithelial cells appears to be the lowest among the three cell types examined.

Both animal and human studies have shown that cortisol has an important role in regulating surfactant synthesis in the fetal lung (Gonzales et al., 1986; Mendelson et al., 1986; Snyder et al., 1981). We provided evidence for the de novo synthesis of SP-A in the fetal membranes (Sun et al., 2006a). Consistent with the induction of SP-A expression by cortisol in the fetal lung, we found that SP-A expression in the fetal membranes was also stimulated by cortisol within the physiological range achieved in the amniotic fluid in late gestation (Sun et al., 2006a), which suggests that cortisol derived from the action of $11 \beta$-HSD1 in the fetal membranes could be important for the induction of SP-A expression both in the fetal lung and fetal membranes.

As previously stated the human fetal membranes are the major sources for prostaglandins (PGE2 and PGF2 $\alpha$ ) at the end of gestation with activation of prostaglandin synthesis in human fetal membranes being one of the key events leading to parturition in both term and preterm labor (Challis et al. 1997; Gibb 1998). Cytosolic PLA $_{2}$ ) and PGHS-2 appear to be the two enzymes catalyzing the rate-limiting steps for the synthesis of PG (Irvine 1982; Kniss 1999). We demonstrated that the apoprotein component of surfactant, SP-A, dose-dependently stimulated PGHS-2 but not $\mathrm{CPLA}_{2}$ and $\mathrm{mPGES}$ expression in chorionic trophoblasts (Sun et al., 2006a). As a consequence of increased PGHS-2 expression, PGE2 release from chorionic trophoblasts was also dose-dependently increased by SP-A (Sun et al., 2006a). Based upon these findings, we speculate that, together with SP-A derived from fetal lung via amniotic fluid, SP-A synthesized locally in the fetal membranes may participate in the initiation of parturition by stimulating prostaglandin synthesis in the fetal membranes at the end of gestation, which may parallel the increased expression of $11 \beta$-HSD1 in the fetal membranes and the consequent dramatic increase of cortisol level in the amniotic fluid by the third trimester.

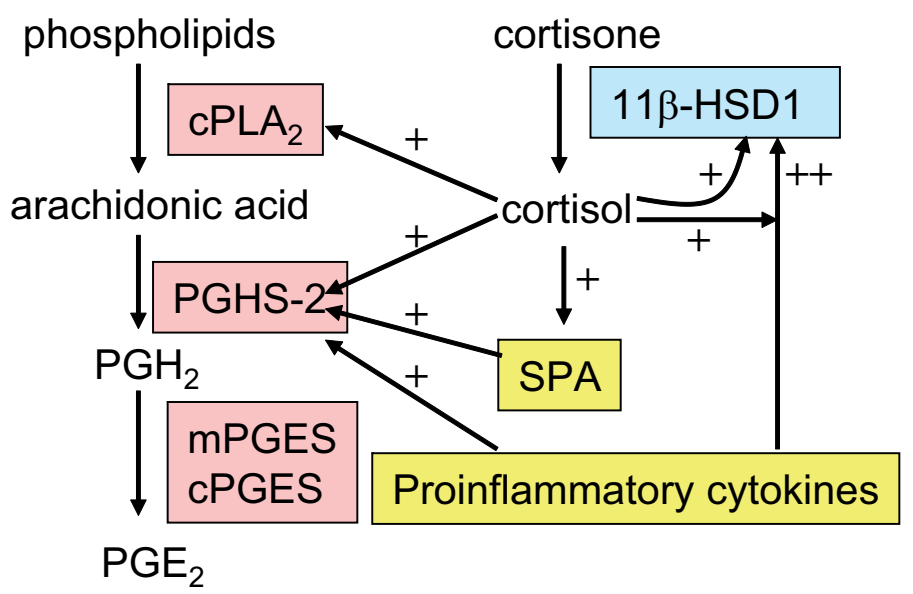

Fig. 2. Regulation of prostaglandin synthesis in fetal membranes. $A$ positive feedback loop is present in the fetal membranes involving stimulation of cortisol and prostaglandin production to promote fetal maturation and initiate parturition. 
Fetal membranes in fetal maturation and parturition

The fetal membranes appear to be a crucial site in integration of signaling for fetal maturation and the onset of parturition. Glucocorticoids have been shown to stimulate PG production in the amnion. This phenomenon has been claimed to be attributed to stimulation of CPLA ${ }_{2}$ and PGHS-2 expression by GCs, particularly in amnion fibroblasts, which are the major cell type producing PGs in the fetal membranes. This is in marked contrast to its reported inhibitory action on the induction of PG production by proinflammatory cytokine These paradoxical effects of GCs are believed to be part of the feed forward loops triggering parturition. Under the influence of glucocorticoids, more PGs would be formed. Prostaglandins in turn could stimulate $11 \beta$-HSD1 activity in the fetal membranes, thus leading to more cortisol regenerated from cortisone in the fetal membranes. Glucocorticoids are required for maturation of fetal organs a requirement for life ex utero post parturition. Expression of $11 \beta-H S D 1$ by the amnion fibroblast will supply active cortisol in increasing concentrations throughout gestation to achieve this. Cortisol per se participates in a feed forward loop stimulating expression of $11 \beta$-HSD1.

\section{Summary}

Taking all these results together, we propose that a positive feedback loop involving glucocorticoids, proinflammatory cytokines, prostaglandins, SP-A and $11 \beta-H S D 1$ is formed locally in human fetal membranes towards term or in preterm labor (Fig. 2). This positive feedback loop would produce abundant biologically active glucocorticoids and PGs in fetal membranes or amniotic fluid, which would ultimately promote fetal organ maturation and initiate parturition.

\section{References}

ALFAIDY N, LI W, MACINTOSH T, YANG K, CHALLIS J. (2003) Late gestation increase in 11beta-hydroxysteroid dehydrogenase 1 expression in human fetal membranes: a novel intrauterine source of cortisol. J Clin Endocrino/Metab88: 5033-5038.

ANDERSON AB, FLINT AP, TURNBULL AC. (1975) Mechanism of action of glucocorticoids in induction of ovine parturition: effect on placental steroid metabolism. J Endocrino/66: 61-70.

AVUNDUK C, EASTWOOD GL, POLAKOWSKI N, BURSTEIN S. (1992) Hydrocortisone has a biphasic effect on rat gastric mucosal prostaglandin generation in vivo: inhibition at low doses, stimulation at high doses. Prostaglandins Leukot Essent Fatty Acids 45: 329-332.

BENNETT PR, CHAMBERLAIN GV, PATEL L, ELDER MG, MYATT L. (1990) Mechanisms of parturition: the transfer of prostaglandin E2 and 5hydroxyeicosatetraenoic acid across fetal membranes. Am J Obstet Gynecol 162: 683-687.

BLANKSTEIN J, FUJIEDA K, REYES FI, FAIMAN C, WINTER JS. (1980) Cortisol, 11-desoxycortisol, and 21-desoxycortisol concentrations in amniotic fluid during normal pregnancy. Am J Obstet Gyneco/137: 781-784.

BLEASDALE J, JOHNSTON J. (1984) Prostaglandins and human parturition: regulation of arachidonic acid metabolism. Rev Perinatal Medicine 5: 151-191.

BLUMENSTEIN M, HANSEN WR, DEVAL D, MITCHELL MD. (2000) Differential regulation in human amnion epithelial and fibroblast cells of prostaglandin $E(2)$ production and prostaglandin $\mathrm{H}$ synthase-2 mRNA expression by dexamethasone but not tumour necrosis factor-alpha. Placenta 21: 210-217.

BOWEN JM, CHAMLEY L, KEELAN JA, MITCHELL MD. (2002) Cytokines of the placenta and extra-placental membranes: roles and regulation during human pregnancy and parturition. Placenta 23: 257-273.

BRO-RASMUSSEN F, BUUS O, TROLLE D. (1962) Ratio cortisone/cortisol in mother and infant at birth. Acta Endocrinol (Copenh) 40: 579-583.
BURKE RK, LUNDY LE, SISSON TR, JAHED FM. (1973) Pulmonary surfactant. Is the fetal adrenal necessary? Obstet Gyneco/41: 833-836.

CASCIANI V, MARINONI E, BOCKING AD, MOSCARINI M, DI IORIO R, CHALLIS JR. (2008) Opposite effect of phorbol ester PMA on PTGS2 and PGDH mRNA expression in human chorion trophoblast cells. Reprod Sci 15: 40-50.

CASEY ML, MACDONALD PC, MITCHELL MD. (1985) Despite a massive increase in cortisol secretion in women during parturition, there is an equally massive increase in prostaglandin synthesis. A paradox? J Clin Invest 75: 1852-1857.

CHALLIS JRG, MATTHEWS SG, GIBB W, LYE SJ. (2000) Endocrine and paracrine regulation of birth at term and preterm. Endocr Rev21: 514-550.

CHANDRABOSE KA, LAPETINA EG, SCHMITGES CJ, SIEGEL MI, CUATRECASAS P. (1978) Action of corticosteroids in regulation of prostaglandin biosynthesis in cultured fibroblasts. Proc Natl Acad Sci USA 75: 214-217.

CHENG YH, NICHOLSON RC, KING B, CHAN EC, FITTER JT, SMITH R. (2000) Glucocorticoid stimulation of corticotropin-releasing hormone gene expression requires a cyclic adenosine $3^{\prime}, 5^{\prime}$-monophosphate regulatory element in human primary placental cytotrophoblast cells. J Clin Endocrino/Metab85: 1937-1945.

CONDON JC, JEYASURIA P, FAUST JM, MENDELSON CR. (2004) Surfactant protein secreted by the maturing mouse fetal lung acts as a hormone that signals the initiation of parturition. Proc Nat/ Acad Sci USA 101: 4978-4983.

COOPER MS, BUJALSKA I, RABBITT E, WALKER EA, BLAND R, SHEPPARD MC, HEWISON M, STEWART PM. (2001) Modulation of 11 beta-hydroxysteroid dehydrogenase isozymes by proinflammatory cytokines in osteoblasts: an autocrine switch from glucocorticoid inactivation to activation. JBone Miner Res 16: 1037-1044.

CROUCH E, WRIGHT JR. (2001) Surfactant proteins a and d and pulmonary host defense. Annu Rev Physio/63: 521-554.

DE COURCY C, GRAY CH, LUNNON JB. (1952) Adrenal cortical hormones in human placenta. Nature 170: 494

DIAZ R, BROWN RW, SECKL JR. (1998) Distinct ontogeny of glucocorticoid and mineralocorticoid receptor and 11beta-hydroxysteroid dehydrogenase types and II mRNAs in the fetal rat brain suggest a complex control of glucocorticoid actions. J Neurosci 18: 2570-2580.

DRAPER N, STEWART PM. (2005) 11 beta-hydroxysteroid dehydrogenase and the pre-receptor regulation of corticosteroid hormone action. JEndocrino/186:251 271.

ESCHER G, GALLI I, VISHWANATH BS, FREY BM, FREY FJ. (1997) Tumor necrosis factor alpha and interleukin 1beta enhance the cortisone/cortiso shuttle. J Exp Med 186: 189-198.

FLINT AP, KINGSTON EJ, ROBINSON JS, THORBURN GD. (1978) Initiation of parturition in the goat: evidence for control by foetal glucocorticoid through activation of placental C21-steroid 17alpha-hydroxylase. J Endocrino/78: 367378.

FLOROS J, PHELPS D. (1997) Pulmonary Surfactant. In Anesthesia: Biologic Foundations. (Eds. Yaksh T, Lynch III C, Zapol W, Maze M, Biebuck J, Saidman L ). Lippincott Raven: Philadelphia, pp 1259-1279.

FORSBERG L, LEEB L, THOREN S, MORGENSTERN R, JAKOBSSON P. (2000) Human glutathione dependent prostaglandin $E$ synthase: gene structure and regulation. FEBS Lett 471: 78-82.

GIANNOPOULOS G, JACKSON K, TULCHINSKY D. (1982) Glucocorticoid metabolism in human placenta, decidua, myometrium and fetal membranes. $J$ Steroid Biochem 17: 371-374.

GIBB W. (1998) The role of prostaglandins in human parturition. Ann Med30: 235241.

GIBB W, LAVOIE JC. (1990) Effects of glucocorticoids on prostaglandin formation by human amnion. Can J Physiol Pharmaco/68: 671-676.

GONZALES LW, BALLARD PL, ERTSEY R, WILLIAMS MC. (1986) Glucocorticoids and thyroid hormones stimulate biochemical and morphological differentiation of human fetal lung in organ culture. J Clin Endocrino/Metab62: 678-691.

GUILLOT L, BALLOY V, MCCORMACK FX, GOLENBOCK DT, CHIGNARD M, SITAHAR M. (2002) Cutting edge: the immunostimulatory activity of the lung surfactant protein-A involves Toll-like receptor 4. J Immuno/ 168: 5989-5992.

GUO C, YANG Z, LI W, ZHU P, MYATT L, SUN K. (2008) Paradox of glucocorticoidinduced cytosolic phospholipase A2 group IVA messenger RNA expression involves glucocorticoid receptor binding to the promoter in human amnion 
fibroblasts. Biol Reprod78: 193-197.

HAN R, TSUI S, SMITH TJ. (2002) Up-regulation of prostaglandin E2 synthesis by interleukin-1 beta in human orbital fibroblasts involves coordinate induction of prostaglandin-endoperoxide $\mathrm{H}$ synthase-2 and glutathione-dependent prostaglandin E2 synthase expression. J Biol Chem 277: 16355-16364.

HAWGOOD S, CLEMENTS JA. (1990) Pulmonary surfactant and its apoproteins. $J$ Clin Invest 86: 1-6.

HOECK WG, RAMESHA CS, CHANG DJ, FAN N, HELLER RA. (1993) Cytoplasmic phospholipase $\mathrm{A} 2$ activity and gene expression are stimulated by tumor necrosis factor: dexamethasone blocks the induced synthesis. Proc Natl Acad SCi USA 90: 4475-4479.

IGNATOVA ID, KOSTADINOVA RM, GOLDRING CE, NAWROCKI AR, FREY FJ, FREY BM. (2009)Tumor necrosis factor-alpha upregulates 11 betahydroxysteroid dehydrogenase type 1 expression by CCAAT/enhancer binding protein-beta in HepG2 cells. Am J Physio/296: E367-E377.

JENKIN G, YOUNG IR. (2004) Mechanisms responsible for parturition; the use of experimental models. Anim Reprod Sci82-83: 567-581.

KARALIS K, GOODWIN G, MAJZOUB JA. (1996) Cortisol blockade of progesterone: a possible molecular mechanism involved in the initiation of human labor. Nat Med 2: 556-560.

KOBAYASHI T, NAKATANI Y, TANIOKA T, TSUJIMOTO M, NAKAJO S, NAKAYA K, MURAKAMI M, KUDO I. (2004) Regulation of cytosolic prostaglandin E synthase by phosphorylation. Biochem J381: 59-69.

KROZOWSKI Z, MAGUIRE JA, STEIN-OAKLEY AN, DOWLING J, SMITH RE, ANDREWS RK. (1995) Immunohistochemical localization of the 11 betahydroxysteroid dehydrogenase type II enzyme in human kidney and placenta. $J$ Clin Endocrinol Metab 80: 2203-2209.

KUDO I, MURAKAMI M. (1999) Diverse functional coupling of prostanoid biosynthetic enzymes in various cell types. Adv Exp Med Bio/469: 29-35.

LAKSHMI V, NATH N, MUNEYYIRCI-DELALE O. (1993) Characterization of 11 beta-hydroxysteroid dehydrogenase of human placenta: evidence for the existence of two species of 11 beta-hydroxysteroid dehydrogenase. J Steroid Biochem Mol Bio/45: 391-397.

LI W, GAO L, WANG Y, DUANT, MYATT L, SUN K. (2006) Enhancement of cortisolinduced 11 beta-hydroxysteroid dehydrogenase type 1 expression by interleukin 1 beta in cultured human chorionic trophoblast cells. Endocrinology 147: 24902495.

LOPEZ BERNAL A, CRAFT IL. (1981) Corticosteroid metabolism in vitroby human placenta, fetal membranes and decidua in early and late gestation. Placenta2: 279-285.

LOPEZ BERNAL A, FLINT A, ANDERSON A, TURNBULL A. (1980) 11betahydroxysteroid dehydrogenase activity in human placenta and decidua. $J$ Steroid Biochem 13: 1081-1087.

LOPEZ BERNAL A, NEWMAN GE, PHIZACKERLEY PJ, TURNBULL AC. (1989) Effect of lipid and protein fractions from fetal pulmonary surfactant on prostaglandin E production by a human amnion cell line. Eicosanoids 2: 29-32.

MA XH, WU WX, NATHANIELSZ PW. (1999) Differential effects of natural and synthetic glucocorticoids on cytochrome 17alpha-hydroxylase (P-45017alpha) and cytochrome P-450 side-chain cleavage (P-450scc) messenger ribonucleic acid in the sheep placenta. Am J Obstet Gynecol180: 1215-1221.

MAHAJAN DK, LONDON SN. (1997) Mifepristone (RU486): a review. Fertil Steril 68: 967-976.

MANCINIJA, BLOOD K, GUAY J, GORDONR, CLAVEAUD, CHAN CC, RIENDEAU D. (2001) Cloning, expression, and up-regulation of inducible rat prostaglandin e synthase during lipopolysaccharide-induced pyresis and adjuvant-induced arthritis. J Biol Chem 276: 4469-4475.

MCKAY LI, CIDLOWSKI JA. (1999) Molecular control of immune/inflammatory responses: interactions between nuclear factor-kappa B and steroid receptorsignaling pathways. Endocr Rev 20: 435-459.

MCKEOWN KJ, CHALLIS JR. (2003) Regulation of 15-hydroxy prostaglandin dehydrogenase by corticotrophin-releasing hormone through a calcium-dependent pathway in human chorion trophoblast cells. J Clin Endocrinol Metab 88: 1737-1741.

MCLEAN M, BISITS A, DAVIES J, WOODS R, LOWRY P, SMITH R. (1995) A placental clock controlling the length of human pregnancy. Nat Med1: 460-463.
MEADOWS JW, EIS AL, BROCKMAN DE, MYATT L. (2003) Expression and localization of prostaglandin $E$ synthase isoforms in human fetal membranes in term and preterm labor. J Clin Endocrinol Metab 88: 433-439.

MENDELSON CR, CHEN C, BOGGARAM V, ZACHARIAS C, SNYDER JM. (1986) Regulation of the synthesis of the major surfactant apoprotein in fetal rabbit lung tissue. J Biol Chem 261: 9938-9943.

MESIANO S, JAFFE RB. (1997) Developmental and functional biology of the primate fetal adrenal cortex. Endocr Rev 18: 378-403.

MITCHELL BF, ROGERS K, WONG S. (1993) The dynamics of prostaglandin metabolism in human fetal membranes and decidua around the time of parturition. J Clin Endocrinol Metab 77: 759-764.

MIYAMURA K, MALHOTRA R, HOPPE HJ, REID KB, PHIZACKERLEY PJ, MACPHERSON P, LOPEZ BERNAL A. (1994) Surfactant proteins A (SP-A) and $D$ (SP-D): levels in human amniotic fluid and localization in the fetal membranes. Biochim Biophys Acta 1210: 303-307.

MURAKAMI M, NAKASHIMA K, KAMEI D, MASUDA S, ISHIKAWA Y, ISHII T, OHMIYA Y, WATANABE K, KUDO I. (2003) Cellular prostaglandin E2 production by membrane-bound prostaglandin $E$ synthase-2 via both cyclooxygenases1 and -2. J Biol Chem 278: 37937-37947.

MURAKAMI S, IWAKID, MITSUZAWA H, SANO H, TAKAHASHI H, VOELKER DR, AKINO T, KUROKI Y. (2002) Surfactant protein A inhibits peptidoglycaninduced tumor necrosis factor-alpha secretion in U937 cells and alveolar macrophages by direct interaction with toll-like receptor 2. J Biol Chem 277: 6830-6837.

MURPHY BE. (1977) Chorionic membrane as an extra-adrenal source of foetal cortisol in human amniotic fluid. Nature 266: 179-181.

MURPHY BE. (1981) Ontogeny of cortisol-cortisone interconversion in human tissues: a role for cortisone in human fetal development. J Steroid Biochem 14: 811-817.

NAKLA S, SKINNER K, MITCHELL BF, CHALLIS JR. (1986) Changes in prostaglandin transfer across human fetal membranes obtained after spontaneous labor. Am J Obstet Gynecol155: 1337-1341.

NESTLER JE. (1993) Interleukin-1 stimulates the aromatase activity of human placental cytotrophoblasts. Endocrinology 132: 566-570.

NEWMAN GE, PHIZACKERLEY PJ, LOPEZ BERNAL A. (1993) Utilization by human amniocytes for prostaglandin synthesis of [1-14C]arachidonate derived from 2-[1-14C]arachidonylphosphatidylcholine associated with human fetal pulmonary surfactant. Biochim Biophys Acta 1176: 106-112.

NEWMAN GE, PHIZACKERLEY PJ, LOPEZ BERNAL A, NOBLE GR, WILLIS AC. (1991) Adsorption of fetal surfactant protein SP-B on the human amnion at term and on amniocytes incubated with fetal surfactant in vitro. Reprod Fertil Dev3: 421-430.

OHRLANDER S, GENNSER G, ENEROTH P. (1976) Plasma cortisol levels in human fetus during parturition. Obstet Gyneco/48: 381-387.

PATEL FA, FUNDER JW, CHALLIS JR. (2003) Mechanism of cortisol/progesterone antagonism in the regulation of 15-hydroxyprostaglandin dehydrogenase activity and messenger ribonucleic acid levels in human chorion and placental trophoblast cells at term. J Clin Endocrinol Metab 88: 2922-2933.

PETRAGLIA F, GARUTI GC, DE RAMUNDO B, ANGIONI S, GENAZZANI AR, BILEZIKJIAN LM. (1990) Mechanism of action of interleukin-1 beta in increasing corticotropin-releasing factor and adrenocorticotropin hormone release from cultured human placental cells. Am J Obstet Gyneco/163: 1307-1312.

POMINI F, PATEL FA, MANCUSO S, CHALLIS JR. (2000) Activity and expression of 15-hydroxyprostaglandin dehydrogenase in cultured chorionic trophoblast and villous trophoblast cells and in chorionic explants at term with and without spontaneous labor. Am J Obstet Gynecol182: 221-226.

PRYHUBER GS, HULL WM, FINK I, MCMAHAN MJ, WHITSETT JA. (1991) Ontogeny of surfactant proteins $A$ and $B$ in human amniotic fluid as indices of fetal lung maturity. Pediatr Res 30: 597-605.

SCHALOSKE RH, DENNIS EA. (2006) The phospholipase A2 superfamily and its group numbering system. Biochim Biophys Acta 1761: 1246-1259.

SECKL JR. (1993) 11 beta-hydroxysteroid dehydrogenase isoforms and their implications for blood pressure regulation. Eur J Clin Invest 23: 589-601.

SECKL JR, CLEASBY M, NYIRENDA MJ. (2000) Glucocorticoids, 11betahydroxysteroid dehydrogenase, and fetal programming. Kidney Int 57: 14121417. 
SERON-FERRE M, LAWRENCE CC, SIITERI PK, JAFFE RB. (1978) Steroid production by definitive and fetal zones of the human fetal adrenal gland. $J$ Clin Endocrinol Metab 47: 603-609.

SHAMS M, KILBY MD, SOMERSET DA, HOWIE AJ, GUPTA A, WOOD PJ, AFNAN M, STEWART PM. (1998) 11Beta-hydroxysteroid dehydrogenase type 2 in human pregnancy and reduced expression in intrauterine growth restriction. Hum Reprod 13: 799-804.

SKANNAL DG, BROCKMAN DE, EIS AL, XUE S, SIDDIQI TA, MYATT L. (1997) Changes in activity of cytosolic phospholipase A2 in human amnion at parturition. Am J Obstet Gyneco/177: 179-184.

SMAILL F. (1996) Infection during pregnancy. In: Hillier S, Kitchener H, Neilson J (eds). Scientific Essentials of Reproductive Medicine. Saunders: London, pp 369.

SMITH BT, WORTHINGTON D, MALONEY AH. (1977) Fetal lung maturation. III. The amniotic fluid cortisol/cortisone ratio in preterm human delivery and the risk of respiratory distress syndrome. Obstet Gyneco/49: 527-531.

SMITH WL. (1992) Prostanoid biosynthesis and mechanisms of action. Am $J$ Physio/263: F181-191.

SNYDER JM, KWUN JE, O'BRIEN JA, ROSENFELD CR, ODOM MJ. (1988) The concentration of the 35-kDa surfactant apoprotein in amniotic fluid from normal and diabetic pregnancies. Pediatr Res 24: 728-734.

SNYDER JM, MENDELSON CR, JOHNSTON JM. (1981) The effect of cortisol on rabbit fetal lung maturation in vitro. Dev Bio/85: 129-140.

STEWART PM, MURRY BA, MASON JI. (1994) Type 211 beta-hydroxysteroid dehydrogenase in human fetal tissues. J Clin Endocrino/Metab78: 1529-1532.

STEWART PM, ROGERSON FM, MASON JI. (1995) Type 211 beta-hydroxysteroid dehydrogenase messenger ribonucleic acid and activity in human placenta and fetal membranes: its relationship to birth weight and putative role in fetal adrenal steroidogenesis. J Clin Endocrinol Metab 80: 885-890.

SUN K, ADAMSON SL, YANG K, CHALLIS JR. (1999) Interconversion of cortisol and cortisone by 11 beta-hydroxysteroid dehydrogenases type 1 and 2 in the perfused human placenta. Placenta 20: 13-19.

SUN K, BROCKMAN D, CAMPOS B, PITZER B, MYATT L. (2006a) Induction of surfactant protein $A$ expression by cortisol facilitates prostaglandin synthesis in human chorionic trophoblasts. J Clin Endocrinol Metab 91: 4988-4994.

SUN K, MYATT L. (2003) Enhancement of glucocorticoid-induced 11betahydroxysteroid dehydrogenase type 1 expression by proinflammatory cytokines in cultured human amnion fibroblasts. Endocrinology 144: 5568-5577.

SUN K, QU X, GAO L, MYATT L. (2006b) Dexamethasone fails to inhibit the induction of cytosolic phospholipase $A(2)$ expression by interleukin-1beta in cultured primary human amnion fibroblasts. Placenta 27: 164-170.

SUN K, YANG K, CHALLIS JR. (1997a) Differential expression of 11 betahydroxysteroid dehydrogenase types 1 and 2 in human placenta and fetal membranes. J Clin Endocrinol Metab 82: 300-305.

SUN K, YANG K, CHALLIS JR. (1997b) Differential regulation of 11 betahydroxysteroid dehydrogenase type 1 and 2 by nitric oxide in cultured human placental trophoblast and chorionic cell preparation. Endocrinology 138: 4912 4920.

TANIKAWA N, OHMIYA Y, OHKUBO H, HASHIMOTO K, KANGAWA K, KOJIMA M, ITO S, WATANABE K. (2002) Identification and characterization of a novel type of membrane-associated prostaglandin E synthase. Biochem Biophys Res Commun 291: 884-889.

TANNIN GM, AGARWAL AK, MONDER C, NEW MI, WHITE PC. (1991) The human gene for 11 beta-hydroxysteroid dehydrogenase. Structure, tissue distribution, and chromosomal localization. J Biol Chem 266: 16653-16658.

TANSWELL AK, WORTHINGTON D, SMITH BT. (1977) Human amniotic membrane corticosteroid 11-oxidoreductase activity. J Clin Endocrinol Metab 45: 721-725.

THOREN S, JAKOBSSON PJ. (2000) Coordinate up- and down-regulation of glutathione-dependent prostaglandin $\mathrm{E}$ synthase and cyclooxygenase-2 in
A549 cells. Inhibition by NS-398 and leukotriene C4. Eur J Biochem 267: 64286434.

TOMLINSON JW, MOORE J, COOPER MS, BUJALSKA I, SHAHMANESH M, BURT C, STRAIN A, HEWISON M, STEWART PM. (2001) Regulation of expression of 11 beta-hydroxysteroid dehydrogenase type 1 in adipose tissue: tissue-specific induction by cytokines. Endocrinology 142: 1982-1989.

TOMLINSON JW, WALKER EA, BUJALSKA IJ, DRAPER N, LAVERY GG, COOPER MS, HEWISON M, STEWART PM. (2004) 11beta-hydroxysteroid dehydrogenase type 1: a tissue-specific regulator of glucocorticoid response. Endocr Rev 25: 831-866.

TSAI MY, JOSEPHSON MW, HANDSCHIN B, BROWN DM. (1983) The effect of prenatal dexamethasone on fetal rat lung prostaglandin synthesis. Prostaglan dins Leukot Med11: 171-177.

UOZUMIN, KUME K, NAGASE T, NAKATANIN, ISHII S, TASHIRO F, KOMAGATA Y, MAKI K, IKUTA K, OUCHI Y, MIYAZAKI J, SHIMIZU T. (1997) Role of cytosolic phospholipase $A 2$ in allergic response and parturition. Nature 390: 618-622.

VAN GOLDE LM, BATENBURG JJ, ROBERTSON B. (1988) The pulmonary surfactant system: biochemical aspects and functional significance. Physiol Rev68: 374-455.

VAN MEIR CA, SANGHA RK, WALTON JC, MATTHEWS SG, KEIRSE MJ, CHALLIS JR. (1996) Immunoreactive 15-hydroxyprostaglandin dehydrogenase $(\mathrm{PGDH})$ is reduced in fetal membranes from patients at preterm delivery in the presence of infection. Placenta 17: 291-297.

WANG Z, TAI HH. (1998) Interleukin-1 beta and dexamethasone regulate gene expression of prostaglandin $\mathrm{H}$ synthase-2 via the NF-kB pathway in human amnion derived WISH cells. Prostaglandins Leukot Essent Fatty Acids 59: 63 69.

WEAVER AJ, SULLIVAN WP, FELTS SJ, OWEN BA, TOFT DO. (2000) Crystal structure and activity of human p23, a heat shock protein 90 co-chaperone. $J$ Biol Chem 275: 23045-23052.

WHITTLE WL, PATEL FA, ALFAIDY N, HOLLOWAY AC, FRASER M, GYOMOREY S, LYE SJ, GIBB W, CHALLIS JR. (2001) Glucocorticoid regulation of human and ovine parturition: the relationship between fetal hypothalamic-pituitaryadrenal axis activation and intrauterine prostaglandin production. Biol Reprod 64: 1019-1032.

WHITWORTH JA, STEWART PM, BURT D, ATHERDEN SM, EDWARDS CR. (1989) The kidney is the major site of cortisone production in man. Clin Endocrinol (Oxf) 31: 355-361.

WU WX, MA XH, YOSHIZATO T, SHINOZUKA N, NATHANIELSZ PW. (2001) Increase in prostaglandin $\mathrm{H}$ synthase 2 , but not prostaglandin $\mathrm{F} 2$ alpha synthase mRNA in intrauterine tissues during betamethasone-induced premature labor and spontaneous term labor in sheep. J Soc Gynecol Investig 8: 69-76.

XUE S, BROCKMAN DE, SLATER DM, MYATT L. (1995) Interleukin-1 beta induces the synthesis and activity of cytosolic phospholipase $\mathrm{A} 2$ and the release of prostaglandin E2 in human amnion-derived WISH cells. Prostaglandins 49: 351-369.

XUE S, SLATER DM, BENNETT PR, MYATT L. (1996) Induction of both cytosolic phospholipase $\mathrm{A} 2$ and prostaglandin $\mathrm{H}$ synthase-2 by interleukin-1 beta in WISH cells is inhibited by dexamethasone. Prostaglandins 51: 107-124.

YANG Z, GUO C, ZHU P, LI W, MYATT L, SUN K. (2007) Role of glucocorticoid receptor and CCAAT/enhancer-binding protein alpha in the feed-forward induction of 11 beta-hydroxysteroid dehydrogenase type 1 expression by cortisol in human amnion fibroblasts. J Endocrino/195: 241-253.

YANG Z. ZHU X, GUO C, SUN K. (2009) Stimulation of 11ß-HSD1 expression by $\mathrm{IL}-1 \beta$ via a C/EBP binding site in human fetal lung fibroblasts. Endocrine 36: 404-411.

YONG PY, HARLOW C, THONG KJ, HILLIER SG. (2002) Regulation of 11 betahydroxysteroid dehydrogenase type 1 gene expression in human ovarian surface epithelial cells by interleukin-1. Hum Reprod 17: 2300-2306. 


\section{Further Related Reading, published previously in the Int. J. Dev. Biol.}

See our recent Special Issue Epigenetics \& Development edited by Saadi Khochbin and Stefan Nonchev at: http://www.ijdb.ehu.es/web/contents.php?vol=53\&issue=2-3

See Special Issue Pattern Formation edited by Michael K. Richardson and Cheng-Ming Chuong at: http://www.ijdb.ehu.es/web/contents. php?vol=53\&issue =5-6

\section{A novel role for Glucocorticoid-Induced TNF Receptor Ligand (Gitrl) in early embryonic zebrafish development \\ Lynn D. Poulton, Kathleen F. Nolan, Corina Anastasaki, Herman Waldmann and E. Elizabeth Patton \\ Int. J. Dev. Biol. in press (doi: 10.1387/ijdb.082841lp)}

Placentation in mammals once grouped as insectivores Anthony M. Carter and Allen C. Enders Int. J. Dev. Biol. (2010) 54: 483-493 (doi: 10.1387/ijdb.082830ac)

Trisomy 21- affected placentas highlight prerequisite factors for human trophoblast fusion and differentiation

André Malassiné, Jean-Louis Frendo and Danièle Evain-Brion

Int. J. Dev. Biol. (2010) 54: 475-482 (doi: 10.1387/ijdb.082766am)

Size regulation does not cause the composition of mouse chimaeras to become unbalanced.

P C Tang and J D West

Int. J. Dev. Biol. (2001) 45: 583-590

Implantation: molecular basis of embryo-uterine dialogue.

B C Paria, H Song and S K Dey

Int. J. Dev. Biol. (2001) 45: 597-605

Stage-dependent responses of the developing lung to retinoic acid signaling.

R Mollard, N B Ghyselinck, O Wendling, P Chambon and M Mark

Int. J. Dev. Biol. (2000) 44: 457-462

Met signaling mutants as tools for developmental studies.

C Ponzetto, G Panté, C Prunotto', A leraci and F Maina

Int. J. Dev. Biol. (2000) 44: 645-653

Structure and developmental expression of mouse Garp, a gene encoding a new leucine-rich repeat-containing protein.

R Roubin, S Pizette, V Ollendorff, J Planche, D Birnbaum and O Delapeyriere

Int. J. Dev. Biol. (1996) 40: 545-555

Immunohistochemical localization of bovine placental retinol-binding protein.

K X Gao, K H Liu and J D Godkin

Int. J. Dev. Biol. (1991) 35: 485-489

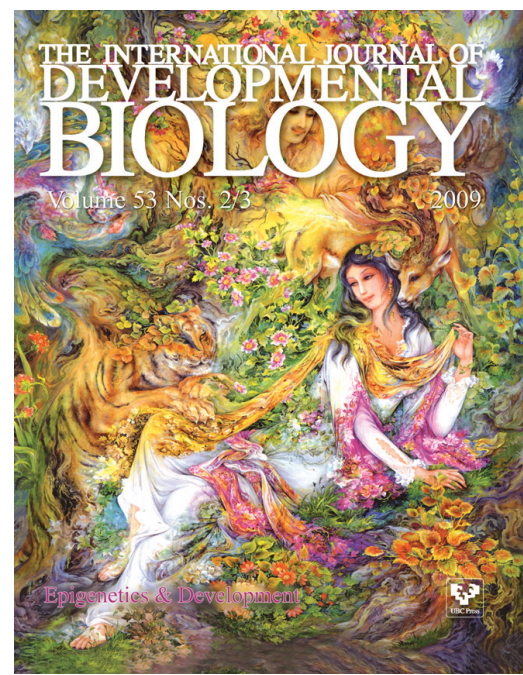

5 yr ISI Impact Factor $(2008)=3.271$

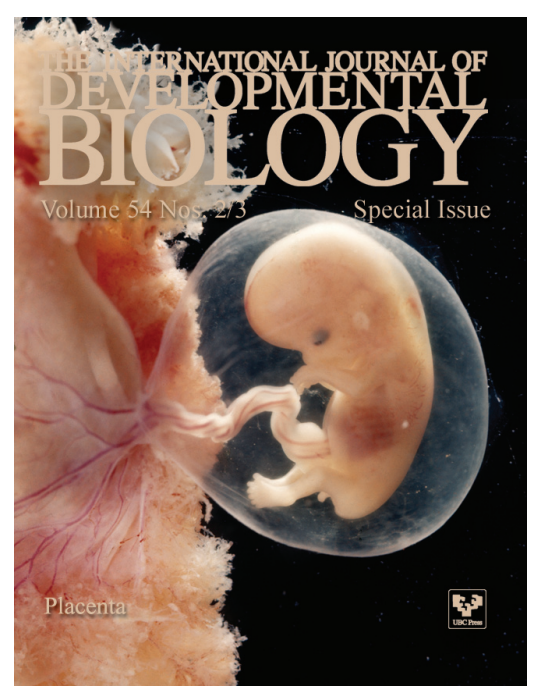

